\title{
FAS and FASL Gene Polymorphisms Are Not Associated with Hepatitis B Virus Infection Based on a Case-Control Study in a Brazilian Population
}

\author{
Bárbara B. Santana, ${ }^{1}$ Maria Luana C. Viégas, ${ }^{1}$ Simone R. S. S. Conde, ${ }^{2}$ \\ Marluísa O. G. Ishak, ${ }^{1}$ Ricardo Ishak, ${ }^{1}$ and Antonio C. R. Vallinoto ${ }^{1}$ \\ ${ }^{1}$ Laboratório de Virologia, Instituto de Ciências Biológicas, Universidade Federal do Pará, Guamá, 66075-110 Belém, PA, Brazil \\ ${ }^{2}$ Fundação Santa Casa de Misericórdia do Pará, 66050-380 Belém, PA, Brazil \\ Correspondence should be addressed to Antonio C. R. Vallinoto; vallinoto@ufpa.br
}

Received 13 August 2013; Accepted 20 October 2013

Academic Editor: Xiaohong Li

Copyright (C) 2013 Bárbara B. Santana et al. This is an open access article distributed under the Creative Commons Attribution License, which permits unrestricted use, distribution, and reproduction in any medium, provided the original work is properly cited.

\begin{abstract}
Objective. This study investigated the association of the single nucleotide polymorphisms (SNPs) in the FAS and FASL genes with the outcome of hepatitis B virus (HBV) infection. Methods. Blood samples were collected from $116 \mathrm{HBV}$-infected patients at the Hospital of the Santa Casa de Misericordia Foundation (Belém, PA, Brazil). Seronegative individuals were used as controls. DNA samples were extracted from the leukocytes and assayed using the polymerase chain reaction (PCR) followed by RFLP analysis with restriction endonucleases. Results. The frequencies of the mutant genotypes for -670FAS (GG), Ivs2nt-124FASL (GG), Ivs3nt169FASL $(\Delta \mathrm{T} / \Delta \mathrm{T})$, and -844FASL (TT) were higher in the HBV patients, and the FAS-1377AA genotype was more frequent in the control group; however, the differences between the allele and genotype frequencies were not statistically significant. When the HBV patient population was divided into two groups (inactive carriers and active chronic hepatitis patients), the mutant genotypes were found to be more prevalent in the active chronic hepatitis group with respect to the FAS gene polymorphisms; however, this difference was not statistically significant. Conclusions. The results suggest that the polymorphisms in FAS and FASL genes are not associated with HBV infection or even with the natural history of the infection in the Brazilian Amazon region.
\end{abstract}

\section{Introduction}

The hepatitis B virus (HBV) is a member of the Hepadnaviridae family and the Orthohepadnavirus genus and shares structural and functional characteristics with other family members, such as tropism for hepatic cells, enveloped viral particles, an incomplete double-stranded DNA genome, and viral replication via reverse transcription [1].

In approximately $3-8 \%$ of adults infected with HBV, the immune defense system cannot destroy the infected hepatocytes and the inflammation process (hepatitis) persists. When the virus persists for more than 6 months, the infection is defined as chronic hepatitis and the chance of spontaneous healing is very low. When the HBV infection becomes chronic, it is a significant cause of hepatic cirrhosis and hepatocellular carcinoma (HCC) $[2,3]$.
In the mid-1990s, Suda and colleagues identified a molecule that initiates the process of programmed cell death (apoptosis). This new molecule was reported to bind to a cell membrane receptor (Fas) encoded by the FAS gene and was termed the Fas ligand (FasL) $[4,5]$.

The FAS gene is located on human chromosome 10q24.1, contains 9 exons and 8 introns, and encodes a 334-amino acid protein. The Fas receptor is expressed on the surface of several types of cells, such as lymphocytes, fibroblasts, epithelial cells, and some endothelial cells, and the peptide is responsible for triggering apoptosis in these cells [6].

The FASL gene is located on chromosome 1q23, is composed of 4 exons, and encodes a 281-amino acid protein. FasL was first described as a cytotoxic protein that is only expressed in activated $\mathrm{T}$ cells. However, it is now known that FasL is present in many other cell types in various 
organs, such as the brain, eyes, placenta and testicles. This protein has been associated with the mechanism of "immune privilege," protecting the organs from inflammation through the activation of apoptosis [7, 8]. Furthermore, this ligand is a major mediator of the cytolytic action of CD8+ T lymphocytes and natural killer cells [9].

The association of the FAS and FASL gene polymorphisms with many types of carcinomas (prostate cancer, breast cancer, nonsmall cell lung cancer, renal cell carcinoma and epithelial ovarian cancer) has been reported over the last 5 years [10-20]. Additionally, these polymorphisms are associated with various other pathologies, including infectious diseases [21-24]. This study investigated whether the single nucleotide polymorphisms (SNPs) in the FAS and FASLG genes (rs1800682, rs2234767, rs5030772, rs503064, and rs763110) are associated with $\mathrm{HBV}$ infection in the Brazilian Amazon region.

\section{Materials and Methods}

2.1. Study Population and Sample Collection. Following approval by the research ethics committee of the Santa Casa de Misericórdia do Pará Foundation, 116 hepatitis B-infected patients under treatment at a renowned hepatology clinic in Belém (PA, Brazil) were briefed about the project and selected for this study. The patients were divided into the following two groups: (A) inactive carriers, defined as $\mathrm{HBeAg-negative}$ and exhibiting a viral load lower than 2,000 IU/mL and normal levels of alanine aminotransferase (10 to $49 \mathrm{U} / \mathrm{L}$ ); and (B) patients with chronic active hepatitis with or without cirrhosis, defined as HBeAg-negative or -positive and exhibiting a high viral load, a liver biopsy with inflammatory activity or fibrosis greater than or equal to 2 on the METAVIR scale, and high levels of alanine aminotransferase ( $\geq 50 \mathrm{U} / \mathrm{L})$. The control group consisted of 235 seronegative subjects. After the laboratory and clinical diagnoses, the individuals signed an informed consent form, the blood samples were collected in vacutainer tubes containing the anticoagulant $\mathrm{K}_{3}$-EDTA, and plasma and leukocyte samples were prepared. The samples were sent to the Virology Laboratory at the Institute of Biological Sciences of the Federal University of Para (Belem, Para, Brazil) and were stored at $-20^{\circ} \mathrm{C}$ before use.

2.2. Polymorphism Analysis. Genomic DNA was extracted from the leukocytes using the Puregene kit (Gentra Systems, Inc., USA). The FAS and FASL gene polymorphisms were identified using PCR. The amplification was performed in a final volume of $30 \mu \mathrm{L}$ containing $500 \mathrm{ng}$ total DNA, $0.2 \mu \mathrm{M}$ of each dNTP, $5 \mathrm{pmol} / \mu \mathrm{L}$ of each primer, $2.0 \mathrm{mM} \mathrm{MgCl}_{2}$, $50 \mathrm{mM} \mathrm{KCl,} 10 \mathrm{mM}$ Tris- $\mathrm{HCl}(\mathrm{pH} \mathrm{8.3)}$ ) and $1.0 \mathrm{U}$ Taq DNA polymerase.

The primers used for the amplification of the FAS and FASLG promoter regions were as follows: $5^{\prime}$-CTA CCT AAG AGC TAT CTA CCG TTC-3' (forward) and $5^{\prime}$-GGC TGT CCA TGT TGT GGC TGC-3' (reverse) for the FAS-670 A>G polymorphism; 5' -TGT GTG CAC AAG GCT GGC GC-3' (forward) and $5^{\prime}$-TGC ATC TGT CAC TGC ACT TAC CAC
CA-3' (reverse) for the FAS-1377 G>A polymorphism; 5' GCA GTT CAG ACC TAC ATG ATT AGG AT-3' (forward) and $5^{\prime}$-CCA ATT CTC ACC TGT ACC TTC-3' (reverse) for FASLG IVS2nt -124 A>G; 5'-AGG AAA GGA CTT CAA AGC CTA-3' (forward) and $5^{\prime}$-TTG ATG CAT CAC AGA ATT TCG TC-3' (reverse) for FASLG IVS3nt-169 T $>\triangle \mathrm{T}$; and $5^{\prime}$-CAA TGA AAA TGA ACA CAT TG-3' (forward) and $5^{\prime}$-CCC ACT TTA GAA ATT AGA TC-3' (reverse) for the FASLG-844 C>T polymorphism. The amplification reactions were performed following previously described protocols [25, 26].

The PCR products were digested as described previously using five different restriction endonucleases, $M v a \mathrm{I}, B s t U \mathrm{I}$, FokI, HincII, and DraIII, to distinguish the FAS-670> G, FAS-1377 G>A, FASL IVS2nt-124 A>G, FASL IVS3nt-169 $\mathrm{T}>\Delta \mathrm{T}$, and FASL-844 $\mathrm{C}>\mathrm{T}$ polymorphisms, respectively. The digestion products included three fragments (184, 47 and $101 \mathrm{bp}$ ) for the $-670 \mathrm{G}$ allele, two fragments (104 and $18 \mathrm{bp}$ ) for the $-1377 \mathrm{G}$ allele, two fragments $(210,29 \mathrm{bp})$ for the $-124 \mathrm{G}$ allele, two fragments (162 and $23 \mathrm{bp}$ ) for the -169 $\mathrm{T}$ allele and two fragments (66 and $19 \mathrm{bp}$ ) for the $-844 \mathrm{~T}$ allele.

Both the PCR and RFLP products were visualized following electrophoresis $(100 \mathrm{~V} / 45 \mathrm{~min})$ on $4 \%$ agarose gels containing $5 \mu \mathrm{L}$ SYBR Safe DNA gel stain in $1 \mathrm{x}$ TAE buffer (the $40 \mathrm{x}$ TAE stock buffer contained $1.6 \mathrm{M}$ Tris base, $0.8 \mathrm{M}$ sodium acetate and $40 \mathrm{mM}$ EDTA $\mathrm{Na}_{2}$ per $1 \mathrm{~L}$ of deionized water) via transillumination using ultraviolet light.

2.3. Statistical Methods. The allele and genotype frequencies were obtained through direct counts, and a comparative analysis of the frequencies between the studied groups was performed using the $\mathrm{G}$ test. The association of the polymorphisms with the risk for $\mathrm{HBV}$ infection or chronic infection was estimated using multiple logistic regression. BioEstat v5.3 software was used to determine the significance level of $P=$ $0.05(5 \%)$ for all of the analyses [27].

\section{Results}

The genotype and allele distributions of the FAS and FASL gene polymorphisms are shown in Table 1. The genotype frequencies of the polymorphisms were consistent with HardyWeinberg equilibrium (patients $P=0.6424$ and control $P=$ 0.9074 for -670 FAS; patients $P=0.4476$ and control $P=$ 0.0978 for -1377 FAS; patients $P=0.6061$ and control $P=$ 0.7434 for -124 FASLG; patients $P=0.2084$ and control $P=$ 0.2838 for -169 FASLG; and patients $P=0.2026$ and control $P=0.3474$ for -844 FASLG). Comparison of the FAS and FASL gene polymorphism frequencies in the HBV patients and healthy controls did not reveal statistically significant differences.

The patient group was divided into two subgroups: (1) inactive carriers (IC), who demonstrated seroreactivity but no viral replication and (2) patients with chronic active hepatitis (CAH), including the clinical forms, who demonstrated liver cirrhosis and HCC. The genotypic frequencies of the patients according to their clinical profiles are presented in 
TABLE 1: Comparison of genotype frequencies of the FAS and FASL polymorphisms among the HBV patients and healthy controls.

\begin{tabular}{|c|c|c|c|c|c|}
\hline Genotype profile & $\begin{array}{c}\text { HBV patients } \\
(n=116) n(\%)\end{array}$ & $\begin{array}{l}\text { Healthy controls } \\
(n=235) n(\%)\end{array}$ & Adjusted $\mathrm{OR}^{*}$ & $95 \% \mathrm{CI}$ & $P$ value \\
\hline \multicolumn{6}{|l|}{ FAS-670 A>G } \\
\hline AA & $25(21.55)$ & $51(21.70)$ & & & \\
\hline $\mathrm{AG}$ & $55(47.41)$ & $116(49.36)$ & & & \\
\hline GG & $36(31.04)$ & $68(28.94)$ & & & \\
\hline $\mathrm{AG}+\mathrm{GG}$ & $91(78.45)$ & $184(78.30)$ & 1.0427 & $0.60-1.81$ & 0.9154 \\
\hline \multicolumn{6}{|l|}{ FAS-1377 G>A } \\
\hline GG & $94(81.04)$ & $185(78.73)$ & & & \\
\hline GA & $20(17.24)$ & $44(18.72)$ & & & \\
\hline $\mathrm{AA}$ & $02(01.72)$ & $06(02.55)$ & & & \\
\hline $\mathrm{GA}+\mathrm{AA}$ & $22(18.96)$ & $50(21.27)$ & 0.8623 & $0.49-1.53$ & $0.8283^{\ddagger}$ \\
\hline \multicolumn{6}{|c|}{ Ivs2ntFASLG-124 A>G } \\
\hline AA & $100(86.21)$ & $198(84.26)$ & & & \\
\hline $\mathrm{AG}$ & $15(12.93)$ & $35(14.89)$ & & & \\
\hline GG & $01(00.86)$ & $02(00.85)$ & & & \\
\hline $\mathrm{AG}+\mathrm{GG}$ & $16(13.79)$ & $37(15.74)$ & 0.8724 & $0.45-1.68$ & $0.8936^{\ddagger}$ \\
\hline \multicolumn{6}{|c|}{ Ivs3ntFASLG-169 $\mathrm{T}>\Delta \mathrm{T}$} \\
\hline $\mathrm{TT}$ & $87(75.00)$ & $177(75.32)$ & & & \\
\hline $\mathrm{T} / \Delta \mathrm{T}$ & $25(21.55)$ & $56(23.83)$ & & & \\
\hline$\Delta \mathrm{T} / \Delta \mathrm{T}$ & $04(03.45)$ & $02(00.85)$ & & & \\
\hline $\mathrm{T} / \Delta \mathrm{T}+\Delta \mathrm{T} / \Delta \mathrm{T}$ & $29(25.00)$ & $58(24.68)$ & 0.9987 & $0.59-1.69$ & $0.2403^{\ddagger}$ \\
\hline \multicolumn{6}{|l|}{ FASLG-844 C>T } \\
\hline CC & $51(43.96)$ & $99(42.13)$ & & & \\
\hline CT & $47(40.52)$ & $112(47.66)$ & & & \\
\hline $\mathrm{TT}$ & $18(15.52)$ & $24(10.21)$ & & & \\
\hline $\mathrm{CT}+\mathrm{TT}$ & $65(56.04)$ & $136(57.87)$ & 0.9527 & $0.60-1.52$ & 0.2513 \\
\hline
\end{tabular}

${ }^{*}$ Multiple logistic regression; ${ }^{\dagger}$ Chi-squared test; ${ }^{\ddagger} G$ test.

Table 2. Both the IC and CAH patients demonstrated HardyWeinberg equilibrium. As shown in Table 2, the genotypic differences between the groups were not statistically significant for the FAS or FASL gene polymorphisms.

Finally, the frequency of combined genotypes of the FAS and FASL genes did not differ between the HBV patients and healthy controls (Tables 3 and 4).

\section{Discussion}

The occurrence of genetic variabilities, especially in genes encoding proteins involved in the immune system, is thought to play an important role in the regulation of the host immunity by regulating gene expression. We recently demonstrated a strong association of the FAS-670 A/G single nucleotide polymorphism with HTLV-1 infection as well as with the clinical evolution to TSP/HAM [26]. Therefore, considering that the physiopathology of hepatitis caused by HBV involves the apoptosis of the HBV-infected cells, we have investigated whether the SNPs in the FAS and FASL genes are associated with the risk for $\mathrm{HBV}$ infection and the status of the infected individual as an IC or CAH patient.
Previous studies have described an association between the FAS and FASL gene polymorphisms and infection with HTLV-1 and HSV-2 [26, 28, 29]. However, the data from other studies on HPV and Helicobacter pylori infection [28, 30, 31] are consistent with our data in that there was no evidence of an association between the allele and genotype frequencies of the FAS and FASL genes and the risk for HBV infection or the status of the infected individual as an IC or CAH patient (with or without cirrhosis), even when the combined genotype frequencies were estimated.

The FAS-670 A>G and FAS-1377 G>A polymorphisms occur in the physical location where the STAT1 and SP1 transcriptional factors bind, respectively [32]. The FAS-670 GG and FAS-1377 AA genotypes reduce the binding of the transcription factors STAT1 and SP1 and downregulate the expression of Fas $[25,33]$. Our data suggests that the assumed low expression of Fas due to the presence of the FAS-670 GG and FAS-1377 AA genotypes may not be an important risk factor for $\mathrm{HBV}$ infection or the status of the infected individual as an IC or CAH patient because both genotypes demonstrated similar frequencies among the patients and healthy controls. However, our results do not correlate with 
TABLE 2: Comparison of genotype frequencies of the FAS and FASL polymorphisms among the active chronic hepatitis patients and inactive carriers.

\begin{tabular}{|c|c|c|c|c|c|}
\hline Genotype profile & $\begin{array}{l}\text { Active chronic } \\
(n=89) n(\%)\end{array}$ & $\begin{array}{l}\text { Inactive carrier } \\
(n=27) n(\%)\end{array}$ & Adjusted OR* & $95 \%$ CI & $P$ value ${ }^{\ddagger}$ \\
\hline \multicolumn{6}{|l|}{ FAS-670 A >G } \\
\hline $\mathrm{AA}$ & $19(21.35)$ & $06(22.22)$ & & & \\
\hline AG & $41(46.07)$ & $14(51.85)$ & & & \\
\hline GG & $29(32.58)$ & $07(25.93)$ & & & \\
\hline$A G+G G$ & $70(78.65)$ & $21(77.78)$ & 0.9666 & $0.32-2.89$ & 0.8003 \\
\hline \multicolumn{6}{|l|}{ FAS-1377 G>A } \\
\hline GG & $72(80.90)$ & $22(81.48)$ & & & \\
\hline GA & $15(16.85)$ & $05(18.52)$ & & & \\
\hline $\mathrm{AA}$ & $02(02.25)$ & $0(00.00)$ & & & \\
\hline $\mathrm{GA}+\mathrm{AA}$ & $17(19.10)$ & $05(18.52)$ & 1.0990 & $0.34-3.54$ & 0.6368 \\
\hline \multicolumn{6}{|c|}{ Ivs2ntFASLG-124 A>G } \\
\hline AA & $78(87.64)$ & $22(81.48)$ & & & \\
\hline AG & $11(12.36)$ & $04(14.82)$ & & & \\
\hline GG & $0(00.00)$ & $01(03.70)$ & & & \\
\hline $\mathrm{AG}+\mathrm{GG}$ & $11(12.36)$ & $05(18.52)$ & 0.5348 & $0.16-1.78$ & 0.3328 \\
\hline \multicolumn{6}{|c|}{ Ivs3ntFASLG-169 $\mathrm{T}>\Delta \mathrm{T}$} \\
\hline $\mathrm{TT}$ & $69(77.53)$ & $18(66.67)$ & & & \\
\hline $\mathrm{T} / \Delta \mathrm{T}$ & $17(19.10)$ & $08(29.63)$ & & & \\
\hline$\Delta \mathrm{T} / \Delta \mathrm{T}$ & $03(03.37)$ & $01(03.70)$ & & & \\
\hline $\mathrm{T} / \Delta \mathrm{T}+\Delta \mathrm{T} / \Delta \mathrm{T}$ & $20(22.47)$ & $09(33.33)$ & 0.5594 & $0.21-1.49$ & 0.5499 \\
\hline \multicolumn{6}{|l|}{ FASLG-844 C>T } \\
\hline $\mathrm{CC}$ & $38(42.70)$ & $13(48.15)$ & & & \\
\hline $\mathrm{CT}$ & $39(43.82)$ & $08(29.63)$ & & & \\
\hline $\mathrm{TT}$ & $12(13.48)$ & $06(22.22)$ & & & \\
\hline $\mathrm{CT}+\mathrm{TT}$ & $51(57.70)$ & $14(51.85)$ & 1.2228 & $0.49-3.03$ & 0.3484 \\
\hline
\end{tabular}

${ }^{*}$ Multiple logistic regression; ${ }^{\ddagger} G$ test.

TABLE 3: Combined genotype frequencies of the FAS polymorphisms among the HBV patients and healthy controls.

\begin{tabular}{lccc}
\hline & Genotype profile & $\begin{array}{l}\text { HBV patients } \\
(n=116) n(\%)\end{array}$ & $\begin{array}{l}\text { Healthy controls } \\
(n=235) n(\%)\end{array}$ \\
FAS-670 A>G & FAS-1377 G>A & $25(21.55)$ & $48(20.42)$ \\
AA & GG & $0(00.00)$ & $03(01.28)$ \\
AA & GA + AA & $69(59.48)$ & $137(58.30)$ \\
AG + GG & GG & $22(18.97)$ & $47(20.00)$ \\
AG + GG & GA + AA & &
\end{tabular}

the data reported by Jung et al. [34], which demonstrate a protective effect of the FAS-1377 A $>$ G polymorphism against $\mathrm{HCC}$ in $\mathrm{HBV}$-infected patients due to a reduction in the rate of cell death induced by the Fas-FasL system. In this study, only a small number of patients exhibited cirrhosis or hepatocellular carcinoma, invalidating any comparative analysis regarding this issue. Furthermore, the sample size and the difference in the ethnicity of the two populations in this study are important bias factors.
The FASLG-844 C>T polymorphism is located in the promoter region of the FASLG gene, and the basal expression of this gene is higher in cells carrying the $\mathrm{C}$ allele than in cells carrying the $\mathrm{T}$ allele [35]. Similar to the observations for the FAS gene polymorphisms, our results demonstrate that the presence of genotypes carrying the $\mathrm{C}$ or $\mathrm{T}$ alleles was not significantly different between the patients and controls, and there was no evidence that this polymorphism affects HBV infection. Similar results were observed for 
TABLE 4: Combined genotype frequencies of the FASLG polymorphisms among the HBV patients and healthy controls.

\begin{tabular}{lcccc}
\hline & $\begin{array}{c}\text { Genotype profile } \\
\text { Ivs3ntFASLG-169 }>\Delta \mathrm{T}\end{array}$ & FASLG-844 C>T & $\begin{array}{c}\text { HBV patients } \\
(n=116) n(\%)\end{array}$ & $\begin{array}{c}\text { Healthy controls } \\
(n=235) n(\%)\end{array}$ \\
\hline $\mathrm{AA}$ & $\mathrm{TT}$ & $\mathrm{CC}$ & $31(26.73)$ & $60(25.53)$ \\
$\mathrm{AA}$ & $\mathrm{TT}$ & $\mathrm{CT}+\mathrm{TT}$ & $42(36.21)$ & $84(35.74)$ \\
$\mathrm{AA}$ & $\mathrm{T} / \Delta \mathrm{T}+\Delta \mathrm{T} / \Delta \mathrm{T}$ & $\mathrm{CC}$ & $16(13.79)$ & $35(14.89)$ \\
$\mathrm{AA}$ & $\mathrm{T} / \Delta \mathrm{T}+\Delta \mathrm{T} / \Delta \mathrm{T}$ & $\mathrm{CT}+\mathrm{TT}$ & $11(09.48)$ & $19(08.08)$ \\
$\mathrm{AG}+\mathrm{GG}$ & $\mathrm{TT}$ & $\mathrm{CC}$ & $03(02.59)$ & $04(01.71)$ \\
$\mathrm{AG}+\mathrm{GG}$ & $\mathrm{TT}$ & $\mathrm{CT}+\mathrm{TT}$ & $11(09.48)$ & $29(12.34)$ \\
$\mathrm{AG}+\mathrm{GG}$ & $\mathrm{T} / \Delta \mathrm{T}+\Delta \mathrm{T} / \Delta \mathrm{T}$ & $\mathrm{CC}$ & $01(00.86)$ & $0(00.00)$ \\
$\mathrm{AG}+\mathrm{GG}$ & $\mathrm{T} / \Delta \mathrm{T}+\Delta \mathrm{T} / \Delta \mathrm{T}$ & $\mathrm{CT}+\mathrm{TT}$ & $01(00.86)$ & $04(01.71)$
\end{tabular}

the FASLG IVS2nt-124 A>G and FASLG IVS3nt-169 T/AT polymorphisms, and it is unknown if the presence of these polymorphisms affects FASL expression [17, 22, 36]. In conclusion, we believe that further studies are required, enrolling other ethnic human population groups as well as in vitro assays to reveal the apoptosis pathway, to determine the role of the FAS and FALG gene polymorphisms in HBV infection.

\section{Conflict of Interests}

The authors declare that they have no conflict of interests.

\section{Acknowledgments}

The authors are grateful to all of the subjects involved in this study. The present study was supported by funds from the National Council for Scientific and Technological Development and PROPESP/UFPA.

\section{References}

[1] D. Ganem and R. J. Schneider, "Hepadnaviridae: the viruse and their replication," in Fields Virology, D. Knipe and P. Howley, Eds., vol. 2, pp. 2923-2969, Lippincott, Williams \& Wilkins, Philadelphia, Pa, USA, 4th edition, 2001.

[2] J. N. Zuckerman and A. J. Zuckerman, "Current topics in hepatitis B," Journal of Infection, vol. 41, no. 2, pp. 130-136, 2000.

[3] W. M. Lee, "Hepatitis B virus infection," The New England Journal of Medicine, vol. 337, no. 24, pp. 1733-1745, 1997.

[4] T. Suda and S. Nagata, "Purification and characterization of the Fas-ligand that induces apoptosis," Journal of Experimental Medicine, vol. 179, no. 3, pp. 873-879, 1994.

[5] T. Suda, T. Takahashi, P. Golstein, and S. Nagata, "Molecular cloning and expression of the Fas ligand, a novel member of the tumor necrosis factor family," Cell, vol. 75, no. 6, pp. 1169-1178, 1993.

[6] F. Leithauser, J. Dhein, G. Mechtersheimer et al., "Constitutive and induced expression of APO-1, a new member of the nerve growth factor/tumor necrosis factor receptor superfamily, in normal and neoplastic cells," Laboratory Investigation, vol. 69, no. 4, pp. 415-429, 1993.
[7] T. A. Ferguson and T. S. Griffith, "A vision of cell death: Fas ligand and immune privilege 10 years later," Immunological Reviews, vol. 213, no. 1, pp. 228-238, 2006.

[8] D. R. Green and T. A. Ferguson, "The role of fas ligand in immune privilege," Nature Reviews Molecular Cell Biology, vol. 2, no. 12, pp. 917-924, 2001.

[9] A. Ashkenazi and V. M. Dixit, "Death receptors: signaling and modulation," Science, vol. 281, no. 5381, pp. 1305-1308, 1998.

[10] Y. Li, Y. Hao, S. Kang, R. Zhou, N. Wang, and B. L. Qi, “Genetic polymorphisms in the Fas and FasL genes are associated with epithelial ovarian cancer risk and clinical outcomes," Gynecologic Oncology, vol. 128, pp. 584-589, 2013.

[11] W. Wang, Z. Zheng, W. Yu, H. Lin, B. Cui, and F. Cao, "Polymorphisms of the FAS and FASL genes and risk of breast cancer," Oncology Letters, vol. 3, no. 3, pp. 625-628, 2012.

[12] J. Tian, F. Pan, J. Li et al., "Association between the FAS/FASL polymorphisms and gastric cancer risk: a meta-analysis," The Asian Pacific Journal of Cancer Prevention, vol. 13, pp. 945-951, 2012.

[13] W. Mahfoudh, N. Bouaouina, S. Gabbouj, and L. Chouchane, "FASL-844 T/C polymorphism: a biomarker of good prognosis of breast cancer in the Tunisian population," Human Immunology, vol. 73, pp. 932-938, 2012.

[14] W. Sung, Y. Wang, Y. Cheng et al., "A polymorphic -844T/C in FasL promoter predicts survival and relapse in non-small cell lung cancer," Clinical Cancer Research, vol. 17, no. 18, pp. 59915999, 2011.

[15] P. Shao, Q. Ding, C. Qin et al., "Functional polymorphisms in cell death pathway genes FAS and FAS ligand and risk of prostate cancer in a Chinese population," Prostate, vol. 71, no. 10, pp. 1122-1130, 2011.

[16] J. Zhu, C. Qin, M. Wang et al., "Functional polymorphisms in cell death pathway genes and risk of renal cell carcinoma," Molecular Carcinogenesis, vol. 49, no. 9, pp. 810-817, 2010.

[17] Z. Zhang, L. Wang, E. M. Sturgis et al., "Polymorphisms of FAS and FAS ligand genes involved in the death pathway and risk and progression of squamous cell carcinoma of the head and neck," Clinical Cancer Research, vol. 12, no. 18, pp. 5596-5602, 2006.

[18] J. Park, W. Lee, D. Jung et al., "Polymorphisms in the FAS and FASL genes and survival of early stage non-small cell lung cancer," Clinical Cancer Research, vol. 15, no. 5, pp. 1794-1800, 2009. 
[19] L. Lima, A. Morais, F. Lobo, F. M. Calais-da-Silva, F. E. Calaisda-Silva, and R. Medeiros, "Association between FAS polymorphism and prostate cancer development," Prostate Cancer and Prostatic Diseases, vol. 11, no. 1, pp. 94-98, 2008.

[20] K. D. Crew, M. D. Gammon, M. B. Terry et al., "Genetic polymorphisms in the apoptosis-associated genes FAS and FASL and breast cancer risk," Carcinogenesis, vol. 28, no. 12, pp. 2548-2551, 2007.

[21] M. Nasi, M. Pinti, R. Bugarini et al., "Genetic polymorphisms of Fas (CD95) and Fas ligand (CD178) influence the rise in $\mathrm{CD} 4+\mathrm{T}$ cell count after antiretroviral therapy in drug-naïve HIV-positive patients," Immunogenetics, vol. 57, no. 9, pp. 628635, 2005.

[22] M. Pinti, L. Troiano, M. Nasi et al., "Genetic polymorphisms of Fas (CD95) and FasL (CD178) in human longevity: studies on centenarians," Cell Death and Differentiation, vol. 9, no. 4, pp. 431-438, 2002.

[23] Q. R. Huang and N. Manolios, "Investigation of the -1377 polymorphism on the Apo-1/FAS promoter in systemic lupus erythematosus patients using allele-specific amplification," Pathology, vol. 32, no. 2, pp. 126-130, 2000.

[24] Q. R. Huang, D. Morris, and N. Manolios, "Identification and characterisation of polymorphisms in the promoter region of the human Apo-1/Fas (CD95) gene," Molecular Immunology, vol. 34, no. 8-9, pp. 577-582, 1997.

[25] T. Sun, X. Miao, X. Zhang, W. Tan, P. Xiong, and D. Lin, "Polymorphisms of death pathway genes FAS and FASL in esophageal squamous-cell carcinoma," Journal of the National Cancer Institute, vol. 96, no. 13, pp. 1030-1036, 2004.

[26] A. C. R. Vallinoto, B. B. Santana, E. L. dos Santos et al., "FAS -670A/G single nucleotide polymorphism may be associated with human $\mathrm{T}$ lymphotropic virus-1 infection and clinical evolution to TSP/HAM," Virus Research, vol. 163, no. 1, pp. 178$182,2012$.

[27] M. Ayres, M. Ayres Jr., D. L. Ayres, and A. S. Santos, BioEstat 5. 0: aplicações estatísticas nas áreas de ciências biológicas e médicas, Sociedade Civil Mamirauá, CNPq, Belem, Brazil, 2010.

[28] K. Chatterjee, C. Dandara, U. Gyllensten et al., "A fas gene polymorphism influences herpes simplex virus type 2 infection in South African women," Journal of Medical Virology, vol. 82, no. 12, pp. 2082-2086, 2010.

[29] L. Farre, A. L. Bittencourt, G. Silva-Santos et al., "Fas-670 promoter polymorphism is associated to susceptibility, clinical presentation, and survival in adult T cell leukemia," Journal of Leukocyte Biology, vol. 83, no. 1, pp. 220-222, 2008.

[30] J. Kupcinskas, T. Wex, J. Bornschein et al., "Lack of association between gene polymorphisms of Angiotensin converting enzyme, Nod-like receptor 1, Toll-like receptor 4, FAS/FASL and the presence of Helicobacter pylori-induced premalignant gastric lesions and gastric cancer in Caucasians," BMC Medical Genetics, vol. 12, article 112, 9 pages, 2011.

[31] K. Chatterjee, M. Engelmark, U. Gyllensten et al., "Fas and FasL gene polymorphisms are not associated with cervical cancer but differ among Black and Mixed-ancestry South Africans," BMC Research Notes, vol. 2, article 238, 6 pages, 2009.

[32] F. Rudert, E. Visser, L. Forbes, E. Lindridge, Y. Wang, and J. Watson, "Identification of a silencer, enhancer, and basal promoter region in the human CD95 (Fas/APO-1) gene," DNA and Cell Biology, vol. 14, no. 11, pp. 931-937, 1995.

[33] K. Sibley, S. Rollinson, J. M. Allan et al., "Functional FAS promoter polymorphisms are associated with increased risk of acute myeloid leukemia," Cancer Research, vol. 63, no. 15, pp. 4327-4330, 2003.

[34] Y. J. Jung, Y. J. Kim, L. H. Kim et al., "Putative association of Fas and FasL gene polymorphisms with clinical outcomes of hepatitis B virus infection," Intervirology, vol. 50, no. 5, pp. 369376, 2007.

[35] J. Wu, C. Metz, X. Xu et al., "A novel polymorphic CAAT/enhancer-binding protein $\beta$ element in the FasL gene promoter alters Fas ligand expression: a candidate background gene in African American systemic lupus erythematosus patients," Journal of Immunology, vol. 170, no. 1, pp. 132-138, 2003.

[36] A. Vasilescu, S. C. Heath, G. Diop et al., "Genomic analysis of Fas and FasL genes and absence of correlation with disease progression in AIDS," Immunogenetics, vol. 56, no. 1, pp. 56-60, 2004. 


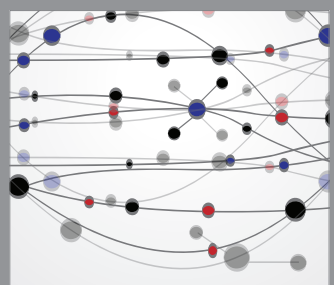

The Scientific World Journal
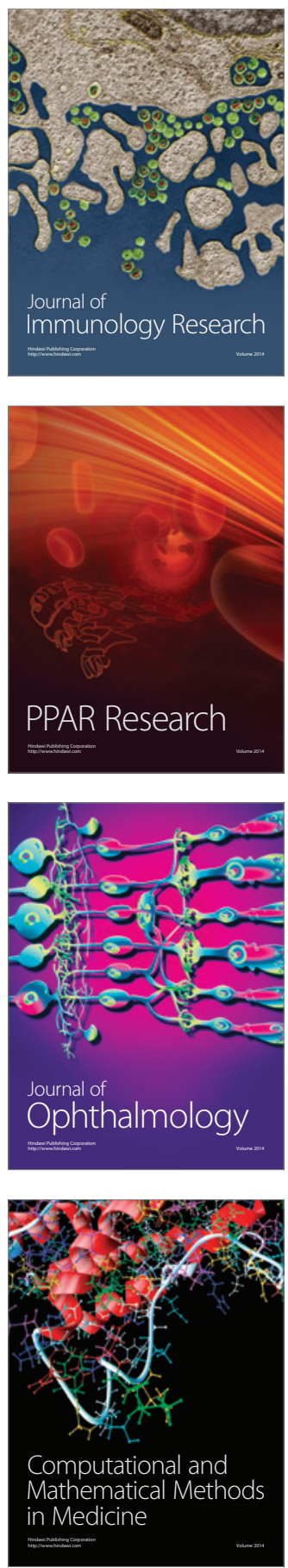

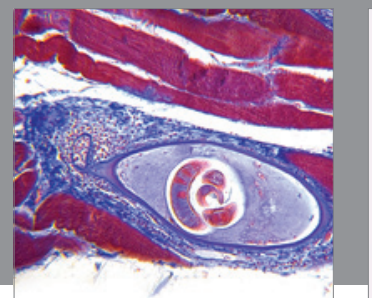

Gastroenterology

Research and Practice
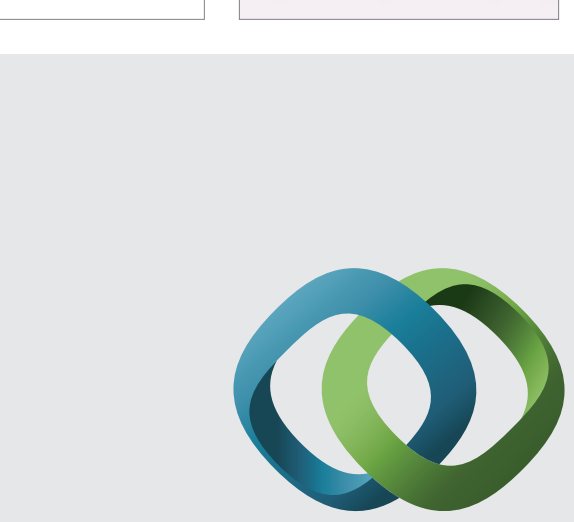

\section{Hindawi}

Submit your manuscripts at

http://www.hindawi.com
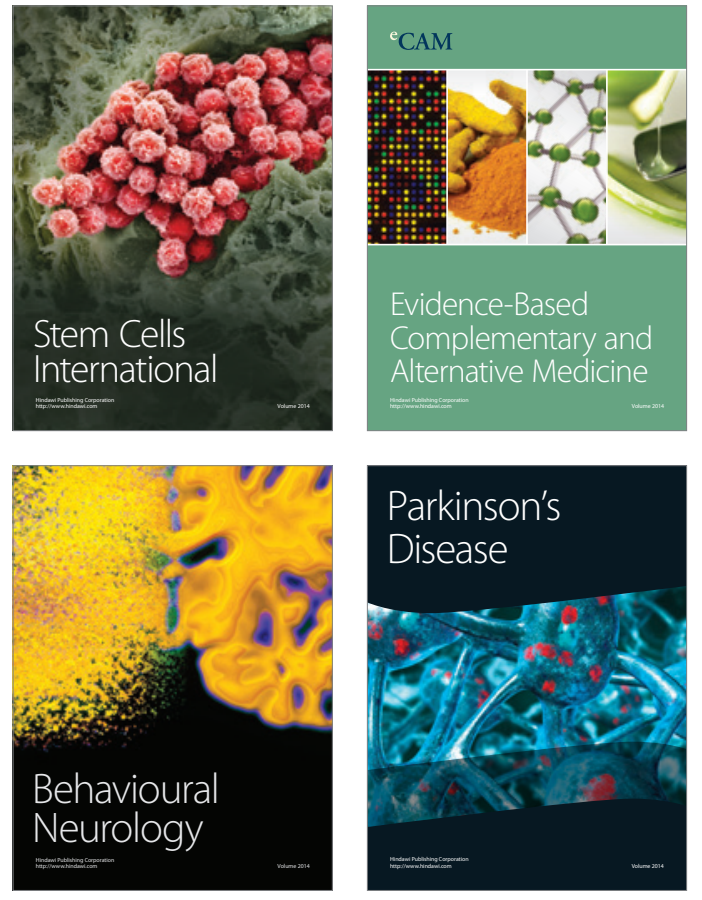
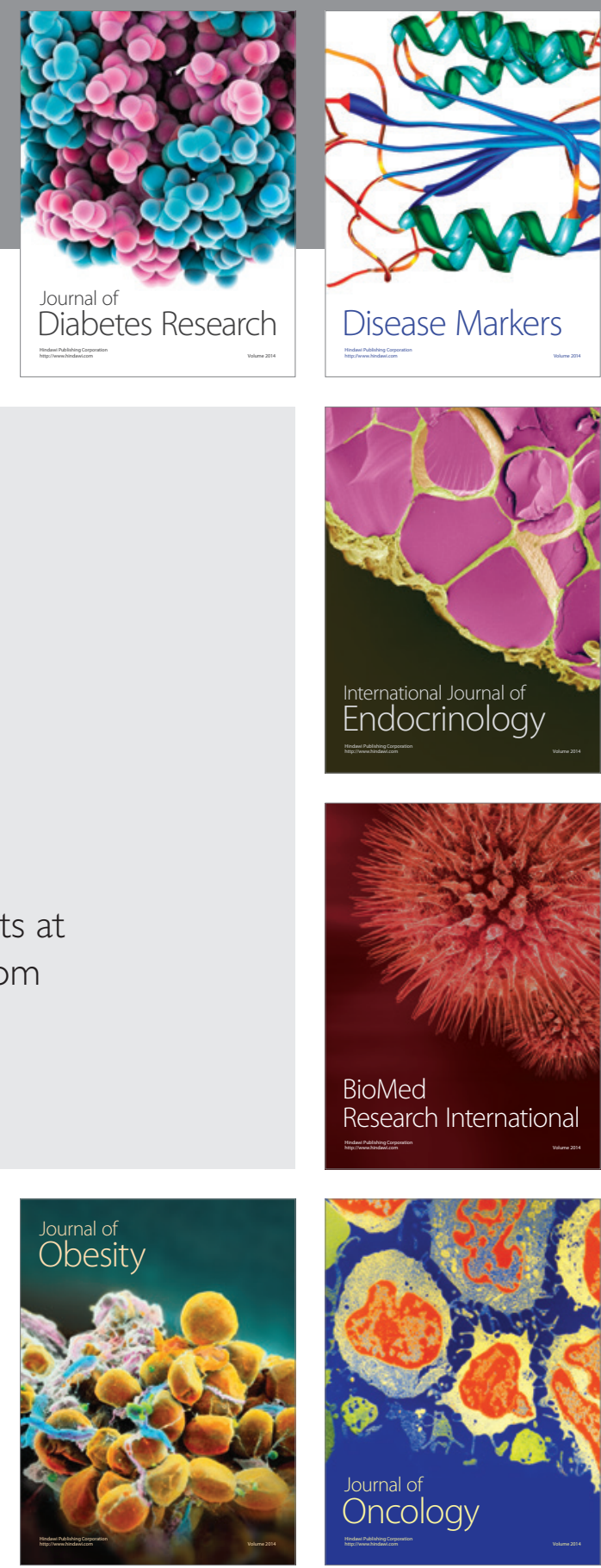

Disease Markers
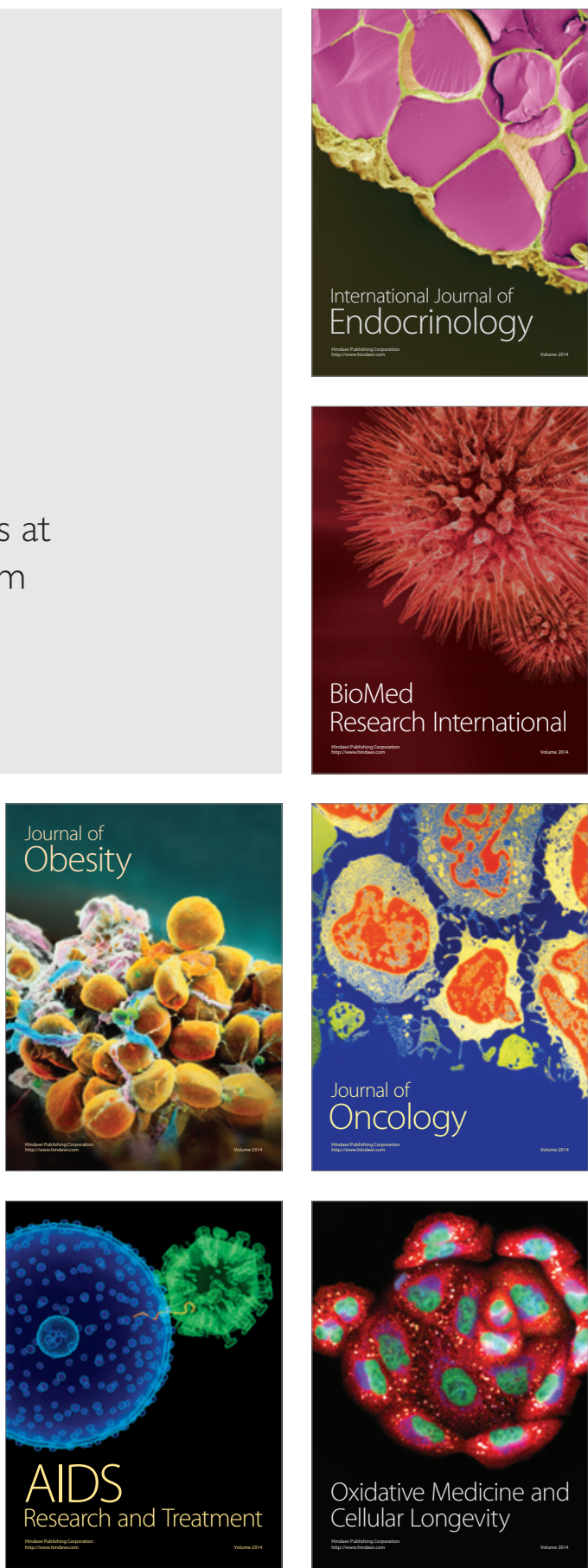